\begin{tabular}{|c|c|c|}
\hline & $\begin{array}{l}\text { International Journal of Current Research } \\
\text { and Academic Review }\end{array}$ & \\
\hline $\begin{array}{l}\text { EXCELLENT } \\
\text { PUBLISHERS }\end{array}$ & Journal homepage: http://www.ijcrar.com & \\
\hline
\end{tabular}

doi: https://doi.org/10.20546/ijcrar.2021.901.005

\title{
Genetic Diversity Assessment and Biological Description of Caster bean crop (Riciunus communis L.)
}

\author{
Kedir Wulchafo Hussen*
}

Ethiopian Institute of Agricultural Research, Wondo Genet Agricultural Research Center, Shashamene, Ethiopia

*Corresponding author

\begin{abstract}
Castor bean is an important nonedible oilseed crop that has many industrial uses. Genetic diversity in a germplasm is the fundamental requirement for crop improvement programs. There are several genetic markers available for assessment of genetic diversity among the genotypes and accessions. Though castor bean is a monotypic, it exhibits wide phenotypic diversity. In castor bean, genetic markers such as agro-morphological characters, biochemical and cytological markers were widely used in characterization of genetic variation in the germplasm from India, Nigeria, Turkey, China, Brazil, Iran, and Ethiopia which indicated a low-to-high-level diversity in the castor bean germplasm depending on the markers and the genotypes studied.
\end{abstract}

Article Info
Accepted: 08 December 2020
Available Online: 20 January 2021
Keywords
Genetic diversity, Characterization,
Phenotypic diversity, Monotypic,
and Nonedible.

\section{Introduction}

Castor bean (Ricinus communis L.) is a perennial or annual crop which is grown throughout tropical and subtropical regions of the world.

Caster bean is the tall and branched shrub produces seeds containing oil which may be extracted by a range of/or combination of processes, such as hydrate presses, continuous screw presses and solvent extraction.

Although the leaves, stems and seeds of the castor plant have been found to contain the poisonous substances ricin and ricinine, the oil does not contain these poisonous substances, and has been used in a wide range of industrial applications including pharmaceuticals, cosmetics, bioplastics, paints, biofuels etc. Castor bean is one of the most promising non-edible oil crops being investigated as biodiesel feedstocks, due to its high annual seed production and yield, and since it can be grown on marginal land and in semi-arid climates. The castor bean meal may be used as a protein source for swine and an organic fertilizer due to its high nitrogen and phosphorus content, but, cold-pressed oil extracted seed meal is known to contain the ricin cytotoxin. It has been reported however, that the toxic effects may be removed by boiling in calcium hydroxide $(\mathrm{pH} 12.5)$ (Barnes et al, 2009). Castor bean may also be used for biomass energy and biochar, which is a valuable soil amendment.

Most castor seed contain approximately $50 \%$ oil which is composed of 80-90\% ricinoleic acid (12-hydroxyl-cis-9octadecenoie acid) (Aismon 1989). This unique hydroxy fatty acid is used in a number of processes to create unique chemicals and polymers. Ricinoleic acid can be 
used in several biobased fuels and industrial products. Pyrolysis of methyl ricinoleate generates methyl I 0undecylenate which can be processed to make Nylon II and a seven-carbon product (heptaldehyde) that can be used as an octane enhancer for combustion engine Fuels. Both of these products are highly valued industrial chemicals. A large variety of other reactions have been described that produce other high value products with great potential as biofuels and industrial polymers. Therefore, the objective of this review paper is to understand and assess the overall diversity, distribution, domestication and economic importance of caster bean crop throughout the world.

\section{Origin and taxonomy of caster bean}

\section{Origin of caster bean}

There are varied opinions about the site of origin of castor. Castor is believed to have four centres of origin, namely (i) Ethiopian-East African region, (ii) Northwest and Southwest Asia and Arabian Peninsula, (iii) Sub continents of India, and (iv) China. Ethiopian-East African region is considered to be the most probable site of origin because of presence of high diversity in Ethiopia (Moshkin, 1986; Carter and Smith, 1987). These centers are also considered to be the first places of castor introduction into cultivation.

Castor beans have been found in ancient Egyptian tombs dating back to 4000 B.C., and the oil was used thousands of years ago in wick lamps for lighting. To many people the castor plant is just an overgrown, undesirable weed, and yet it produces one of nature's finest natural oils

\section{Taxonomy of caster bean}

Castor is a diploid $(\mathrm{x}=10,2 \mathrm{n}=20)$ with few if any natural polyploids (Moshkin, 1986). It belongs to the spurge family (Euphorbiaceae), which contains about 300 genera and 6,300 to 7,500 species (Chan et al., 2010, Singh and Geetanjali, 2015).

Early taxonomists tried to classify castor (Ricinus cummnuis L.) into several subspecies based on phenotypic differences but most botanists now believe all castor belong in the same species. Castor accessions display significant differences in height, branching. Color or growth habit, and many of these phenotypic traits are simply inherited and most accessions will readily intercross.

\section{Description of caster bean plant}

$R$. communis is a shrub-like plant with reddish to purple stems that may reach $4-5 \mathrm{~m}$ in height. The large (10-76 $\mathrm{cm}$ ), umbrella like leaves have 5-9-pointed, finger-like lobes. Long purple leaf-stems are attached near the centers of the leaf blades (Falasca et al., 2012). $R$. communis is monoecious, with separate male and female flowers on the same individual. There are no petals and each female flower consists of a little spiny ovary and a bright red structure with stigma lobes that receives pollen from male flowers. Each male flower consists of a cluster of many stamens which literally smoke as they shed pollen in a gust of wind (Ladda and Kamthane, 2014). Seed size ranges from $0.08-0.9 \mathrm{~g}$ by weight and $0.8-1.9 \mathrm{~cm}$ by height and there are two varieties: small seeded variety and large seeded variety (Akande et al., 2012). The genome of $R$. communis is being sequenced (Chan et al., 2010); the reported assembly covered the genome $4.6 \times$, spanning $350 \mathrm{Mb}$ and 31,237 gene sequences were identified by these authors.

\section{Distribution of caster bean crop}

R. communis is probably a native to North-Eastern Africa (i.e., Somalia and possibly Ethiopia). Currently, naturalized populations of $R$. communis can be found across the African continent, from the Atlantic coast to the Red Sea, from Tunisia to South Africa and on islands in the Indian Ocean. It is widely cultivated and naturalized in tropical and subtropical regions of America and Asia and in many temperate areas of Europe. It naturalizes easily and grows in many areas as a common ruderal plant (DAISIE, 2014; Govaerts, 2014; PROTA, 2014).

\section{Economic importance}

Castor is an important oilseed crop with great utilitarian value in industry, pharmaceutical and agricultural sectors. The seeds contain between $40 \%$ and $60 \%$ oil. Its oil is unique among vegetable oils because the oil is the only commercial source of a hydroxylated fatty acid. The presence of hydroxyl groups and double bonds in the ricinoleic acid imparts unique chemical and physical properties on castor oil that makes the oil a vital industrial raw material. In the last couple of years, demand for castor oil has kept increasing in the international market, assured by more than 700 uses, ranging from medicine and cosmetics to biodiesel, plastics and lubricants. The oil has advantages over petroleum base oils, especially at high and low 
temperatures because of its high boiling and low melting points (Ogunniyi, 2006), and (Mutlu and Meier, 2010). Besides reducing greenhouse gases because of its high oil content, it produces relatively high crop yield with relatively low input.

\section{Castor oil in medicine and cosmetics}

Castor oil is one of natural products that fight several ailments. It contains active ingredients that make it take central position in production of several medicinal and cosmetic products.

Skin diseases/disorders: Castor oil is every effective when it comes to treatment of skin problems like sunburn, acne, ringworm, wrinkles and fine Lines dry skin and stretch marks. It also prevents infections like warts, boils, athlete's foot and chronic itching. The oil is good skin moisturizer and disinfectant of wound.

Hair treatments: Castor oil is mixed with coconut or almond oil to initiate hair growth, thicken of eyebrows and eyelashes. The oil boosts blood circulation to the follicles, leading to faster hair growth. The oil also has omega-6 essential fatty acids, responsible for healthy hair. The oil is also used for correction of bald patches and hair darkening.

Other medicinal uses: Castor oil is a great additive and powerful laxative that serves as remedy for aliments like Multiple Sclerosis, Parkinson's disease, Cerebral Palsy, Pain from Rheumatism, Gastrointestinal Problems, menstrual Disorders, Migraines, Age Spots, Skin Abrasions and Inflammation.

\section{Castor in agriculture}

\section{Castor meal and husk for animal feed}

Detoxified castor meal can be used as feed (ICOA., 1989). Castor meal detoxified by boiling could be added up to $100 \mathrm{gkg}^{-1}$ in broiler finishing diets without deleterious effects (Ani and Okorie, 2009). Castor meal detoxified by autoclaving can replace up to $67 \%$ of the soybean meal in sheep rations (Pompeu, 2009. Substituicao). The husk is a low value by-product that can be used as roughage for ruminants. A sample castor husks containing a considerable amount of seed fragment $\left(60 \mathrm{~g} \mathrm{~kg}^{-1}\right)$ was evaluated for feeding dairy goat. When hay was completely replaced by castor husks, there was reduction (27\%) in milk but increase (28\%) in lipid concentration. The husks were not subjected to any detoxification process and no symptom of toxicity was observed (Santos et al., 2001).

\section{Castor meal as an organic fertilizer}

The use of castor meal as organic fertilizer is very advantageous because of high $\mathrm{N}$ content, fast mineralization, and anti-nematode effects. The mineralization castor meal was evaluated to be 7 times faster than bovine manure and 15 times faster than bagasse of sugarcane. Castor meal has been reported to promote the growth in wheat and castor plants (Gupta et al., 2010) and (Lima et al., 2011). Castor husks can also be used as organic fertilizer but must be blend with a $\mathrm{N}$ rich organic material to provide a better nutrient balance for plant growth (Lima et al., 2006) (Lima et al., 2011).

\section{Castor oil in biodiesel}

Biofuels are becoming big policy and big business as countries around the world looking to decrease petroleum dependence, reduce greenhouse gas (GHG) emissions in the transportation sector, and support agricultural interests. Production of biodiesel from castor oil is technically feasible. The major constraint has been the high price paidfor the oil as industrial oil because of high demand by the chemical industries to manufacture very high value products. Biodiesel produced from castor oil has are markable advantage regarding lubricity because of its high energy value and positive fuel properties (Drown et al., 2001), (Refaat, 2009) and (ICOA, 1989).

\section{Other industrial uses of castor}

Castor oil can be used as bio-based polyol in the polyurethane industry. In food industry, castor oil is used in food additives, flavoring, candy, and as mold inhibitor (Wilson et al., 1998). The oil can also be used to prevent rice, wheat and pulses from rotting. The oil is also important raw material in paints and nylon industries. Castor wax produced by hydrogenation is used in polish, electrical condensers, carbon paper and as a solid lubricant.

\section{Castor seed as food condiment}

The white, large seeds of castor are important sources of food condiment called Ogiriin the South-Eastern part of Nigeria. The condiment is believed to improve eye vision. The condiment is prepared by: removing the seed 
coat, boil the cotyledons for $8-10$ hours, sieve the cotyledons,

leave the sieved cotyledons to stand for $12-14$ hours then ground the cotyledon to paste as Ogiri. The condiment can be stored for several months as the oil content inhibits the growth of microbes.

\section{Genetic diversity of castor (Recinius communis L.)}

Uncultivated wild and semi-wild castor plants are widespread not only in its Centers of Origin, but also outside. They represent the tremendous variability existing in the species. Castor had been adapted to diverse ecological niches. Therefore, ecological heterogeneity, stresses, natural selection and its interaction with other evolutionary forces including mutation, migration and genetic drift might have contributed greatly to genetic diversity according to circumstances in the natural niches. Studies on genetic diversity are necessary to elucidate and categorize the naturally existing variability. Genetic diversity in castor was assessed mostly by using agro-morphological traits and to some extent by molecular techniques. The vast worldwide castor collections reported were poorly studied and barely tapped for castor genetic improvement.

\section{Diversity for morphology}

There are a very few documented evidences describing morphological diversity in castor. Earlier taxonomists and botanists studied morphological diversity with the purpose of classifying the genus Ricinus. Moshkin (1986) reported existence of diverse morphological variants in many parts of the world for plant height, branching, stem color, leaf size, waxy coating, length, shape and compactness of raceme, pedicle length, size and shape of capsule and seed. (Woodend, 1993) described white, black and dark brown seed with varying mottling intensity, dark green and dark red color stem, prostrate to columnar growth habit, weak-framed, robust and tree like plant types among collections.

Most of the morphological variants observed in other Centers of Origin and tropical and sub-tropical countries. Twenty-four morphological descriptors were developed to characterize each germplasm accession. The most frequent morphological traits are medium tall, red and green colored woody stem, low to high number of nodes on main stem, divergent branching, waxy coating on stem, medium and semi-cup shaped leaves, medium long, loose, conical shaped racemes, medium sized, nondehiscent, green, spiny capsules, and medium sized, oval shaped, brown-colored seeds with conspicuous mottling on seed coat and caruncle (Anjani, 2000).

\section{Variation of sex tendency}

Castor inflorescence is monoclinous monoecious raceme bearing female flowers near the apex and male flowers proximally. Great variation exists in proportion of male to female flowers on a raceme. The proportion of female flowers in the racemes of a given plant is a measure of female tendency and that of male flowers is a measure of male tendency. There are several sex variants (Joshi, 1926) such as plants having racemes with only pistillate flowers, with only male flowers and with various proportions of pistillate and staminate flowers interspersed along the entire length of raceme. Occasionally, castor inflorescence terminates with a hermaphrodite flower which invariably drops off before capsule setting.

Roxburgh (1874) first discovered a female wild castor plant. A study of sex variation by (Shifriss, 1960) revealed existence of recessive and dominant female mutants. Dominant female mutants are spontaneous and genetically unstable. Such female plants produce female racemes at first, but later revert to production of monoecious racemes having both male and female flowers. Spontaneous occurrence of unstable pistillate mutants ranging in frequency from 1:375 to 1:16400 in different castor populations was reported (Shifriss, 1957). Femaleness transmits higher to progeny through female inflorescences of sex reversal castor plants, than through reverted monoclinus monoecious inflorescences of the same plant (Jacob and Atsmon, 1965). (Brigham, 1967) reported a single recessive gene control of female sterility in castor. A colchicine derived trisomic plant from the variety Adam dam produced only male flowers (Jacob, 1963). Genetic mechanism governing interspersed sexuality was not well understood as the differentiation of interspersed staminate flowers is quantitative in nature and is greatly influenced by nongenetic variations. (George and Shifriss, 1967) reported that the combined action of two independent genes, id1, and id 2 in some genetic backgrounds resulted in a high level of expressivity of interspersed staminate flowers under a wide range of environmental conditions. The level of expressivity of interspersed staminate flowers appeared to be dependent upon dosage of these genes. In addition to these genes, there also exist some other genes for interspersed staminate flowers whose 
expression is particularly sensitive to environmental fluctuation. (Zimmerman and Smith, 1966) postulated polygenic inheritance of environmentally sensitive interspersed staminate flowers.

\section{Diversity of caster oil content and quality}

Castor oil is identified as a potential feed-stock for biofuel production because of its proven technical and ecological benefits and guaranteed sale (Conceicao et al., 2007). Oil content ranging from 42 to $58 \%$ was reported by Popova (1926) in a series of old castor collections. (Da Silva Ramos et al., 1984) observed wide variability for seed oil content ranging from 39.6 to $59.5 \%$ among 36 castor collections from Brazil. (Bhardwaj et al., 1996) reported 22-44\% oil content in 72 USDA castor accessions collected from 15 countries.(Rojas-Barros et al., 2004) reported $44.8-56.5 \%$ oil content among 191 USDA castor germplasm collections. Oil content ranging from 36.6 to $53.8 \%$ was observed in six Nigerian collections (Okoh et al., 2003). Indian germplasm collection at DOR exhibited $28-55 \%$ oil content. (Verma et al., 2007) reported 46-56\% oil content in30 Indian castor genotypes using Soxhlet extraction method.

Castor meal is unsuitable to feed animals because of presence of two toxic endosperm proteins viz., ricin and Ricinus communis agglutinin (RCA). A major application of ricin, currently being explored, is in the construction of immunotoxins. Cost of usage of ricin in clinical trials is very high because of low ricin productivity and difficulty in purification. Castor genotypes with high ricin concentration would be advantageous to produce high quantity of ricin for pharmaceutical industry. Ricin has the potential to be used as a poisonous biological warfare and bioterrorism agent, which has limited domestic castor production in the USA. Development of non-toxic castor cultivars with extremely reduced levels of ricin would eliminate the dangers and improve the economics of castor oil production. Ricin content ranging from 2.9 to $10.8 \mathrm{mg} / \mathrm{g}$ of meal was estimated among 51 USDA castor accessions (Bhardwaj et al., 1996). (Pinkerton, 1997) reported remarkable diversity for ricin + RCA120 concentration ranging from 1.9 to $16 \mathrm{mg} / \mathrm{g}$ among 263 accessions received from USDA. Very low concentrations of ricin + RCA120 were estimated in two former USSR introductions viz., PI $257654(1.5 \mathrm{mg} / \mathrm{g})$ and PI $250623(1.8 \mathrm{mg} / \mathrm{g})$ and in an Iranian introduction PI $222829(1.9 \mathrm{mg} / \mathrm{g})$. The5 USDA collections (PI 182987, PI 257657, PI 258368, PI 267802, PI486318), which were introduced from India, Soviet Union, Brazil and Peru, respectively, contained $2.4-3.9 \mathrm{mg} / \mathrm{g}$ of these two toxins (Pinkerton, 1997; Pinkerton et al., 1999; (Auld et al., 2001). TTULRC, an open-pollinated germplasm population of castor having very low concentration of ricin + RCA120 (1.86 mg/g) was developed at Texas Tech University, Texas. Seed of TTU-LRC can be obtained directly from the Plant Genetic Resources Conservation Unit in Griffin, GA as PI 631156 (Auld et al., 2003).

\section{Molecular diversity of caster}

Castor has the lowest DNA C-value known among the Euphorbiaceae species $(2 \mathrm{C}=0.46 \mathrm{pg})$ (http://data.kew.org/cvalues) and has moderate size genome with 350 Mbp (Armuganathan and Earle, 1991). Cultivar, Hale, was used to sequence castor genome(Chan et al., 2010). Genetic polymorphism in ricin gene family, oil metabolism genes and disease resistant genes was analysed using the draft genome. Twenty-eight putative genes for ricin family,71 genes involved in biosynthesis of fatty acids and triacylglyceros, mainly ricinoleic acid and 121 predicted proteins involved in disease resistance were identified. A preliminary sequencing of preproricin genes in 63 plants of USDA worldwide castor collection showed presence of a large number of nucleotide polymorphisms (Connell and Skowronski, 2006). Molecular markers such as RAPD, AFLP, ISSR and SNP were successfully used to characterize genetic variability among castor germplasm collections. The molecular diversity investigations conducted by Bajay, 2010), Gajera et al., 2010) and (Zheng et al., 2010) using SSR, RAPD, ISSR and SRAP markers showed existence of large genetic variation in castor germplasm collections. (Allan et al., 2008) reported low genetic diversity using AFLP and SSR markers among 41 accessions from USDA. These accessions representing five continents and 35 countries were not geographically structured. It was suggested that the low genetic diversity might be due to one or more factors like sampling strategy that could not capture the full extent of genetic variation in the species, artificial variation due to long-term storage and seed regeneration and intense selection followed by domestic ation of a limited number of castor genotypes, which are widely propagated for agro-economic and horticultural traits. (Foster et al., 2010) also reported low genome-wide SNP variation in 152 USDA global accessions possessing phenotypic variation including dwarf, large leaf, dark green to crimson leave color, small to large seed, brown, tan and reddish-brown colored seed, early to late maturity and racemes of various sizes. Geographic 
structure was not observed in these collections despite coverage of substantially more genome by the SNP data than AFLPs and SSRs. It was argued that the multiple sources of introductions to individual countries were the most plausible reason for the non-geographic structuring of worldwide germplasm. However, the sampling strategies implemented and the less genome coverage by molecular primers seem to be the most probable factors for low diversity estimations. These studies are fragmentary and unsystematic, cannot be readily combined to provide a comprehensive view of genetic diversity present in Ricinus. Comprehensive and systematic investigations involving large collections, representing genome-phenome diversity underdiverse ecological niches are needed to have a credible picture of diversity.

\section{Biological and morphological diversity of caster growth of caster}

Castor seed takes around 10- 15 days to germinate depending on the prevailing temperatures. The plants may attain a height of $30-90 \mathrm{~cm}$ but the same varieties if they planted in fertile soils with good rainfall conditions may attain heights of 3 to 4 meters. As a field crop it is not advantageous to have plants taller than 1.5 to 2.0 meters. If they are taller harvesting becomes very difficult and damage due to heavy winds is also severe.

As castor plant is branching type it produces racemes in the main shoot as well as on the branches of primary, secondary and tertiary order. The main stem terminates in a raceme and this is known as the main spike. This is followed by side raceme which gets ready for harvest at different intervals.

Usually, the main raceme ready for harvest by 180 days after sowing. The local castor varieties have shattering nature and thus periodical pickings are necessary. The inflorescence first appears in the form of a bud. For the bud to develop into a raceme it takes 8-15 days. When all the flowers on spike have fully emerged, it is easy to make out whether the spike is mostly female, partially female or otherwise.

In castor both the pistillate and staminate flowers are borne on the same peduncle and thus forms a monoecious raceme. Usually, the pistillate flowers are at the top and the staminate flowers at the base. Removal / Nipping of axillary buds on the main stem soon after the initial emergence of the primary raceme reduce the duration of crop and thus facilitates to grow another crop after castor. Nipping of axillary buds results in full and synchronous development of racemes/spikes.

The castor plant has a slender tap root whose size and depth depend on the type of soil, soil moisture and temperature and variety. The number and extent of lateral roots arising from the tap root vary and these are restricted to the upper 30-inch region. Secondary roots mostly spread horizontally and grow about 3 to 4 feet. Tertiary roots are not very long, hardly 12 " to 18 ". Root hairs are absent in castor.

\section{The root system}

The root system consists of main tap root, secondary roots and tertiary roots. The tap root looks like an extension of the stem below the soil. The secondary roots are branches of the tap root and these are restricted to the upper 30-inch region. The secondary roots mostly travel parallel to the ground, with a slight bend downwards. These grow to about three or four feet.

The tertiary roots are not very long, hardly 12 to 18 inches. Root hairs have not been noticed in castor.

\section{Height of plants}

Like branching the plant height is also greatly influenced by environment. It is usually found that in poorer types of soils and scarcity of moisture, the plants attain heights of 30-90 cm but the same varieties if planted in fertile soils with good rainfall conditions may attain heights of 3.0 to 4.0 meters. As a field crop it is not advantageous to have plants taller than 1.5 to 2 meters. If they are taller, harvesting becomes very difficult and damage due to heavy winds is also severe.

\section{Color of stem}

The color of the stem is variable. Pink and Sulphur white stems are to be found mainly in ornamental varieties grown in gardens, although these plants thrive well in the fields also.

The stem colors are divided into five categories viz.

1. Bright green

2. Green with reddish-bluish on the sunny side

3. Caranine or rose red

4. Mahogany red and

5. Purple (dark red) 
Leaves

The size of the leaf varies in different varieties. Certain varieties are characterized by large leaves where as others bear only small leaves. The leaves are simple and palmate. The number of lobes vary from 7-11. There are very few leaves either with 7-11 lobes and great majority have 9-10 lobes. The length of the leaf (measured from base of leaf to tip of mid lobe) varies a great deal. The maximum length is $33 \mathrm{~cm}$. The leaf is usually green, but this is associated with the color of the stem. In case of green stem, the leaf and mid ribs are all green. In case of red stem, the young leaves have red tinge which becomes green when the leaf is fully developed; but the mid rib maintains the reddish tinge.

\section{Inflorescence of caster}

Usually, the main axis and the branches terminate in inflorescence. The inflorescence first appears in the form of a bud. The time required for the appearance of such bud from seeding varies with different varieties. For the bud, to develop into a raceme it taken 8 to 15 days. When all the flowers on a spike have fully emerged, it is easy to make out whether the spike is mostly female, partially female or otherwise.

\section{Male flowers (Male spike)}

Calyx membranous, splitting into 3-5 valvate segments, stamens vary many filaments crowded, variously connate or in branching clusters, anther cells distinct, distant, sub globose, divergent, pistillode.

Female flowers (Female spike)

Calyx spathaceous, caducous, ovary 3 celled, styles short or long, spreading. Often very large, entire 2-fid or 3partite, feathery or papillose; cells 1 ovuled. Capsules of 3,2-valved cocci, Seeds oblong, testa crustaceous, albumen fleshy, cotyledons broad flat.

\section{Nature of spike}

In castor both the pistillate and staminate flowers are borne on the same peduncle and thus it forms a monoecious raceme. Usually, the pistillate flowers are at the top and the staminate ones at the base. In normal inflorescence the pistillate flowers occupy about 30-50\% of the portion of the spike and the remaining lower portion by staminate flowers. The proposition of the part of raceme occupied by each type of flower gives a different appearance to the spike and these form different types.

These types could be classified into three major groups. 1. Mostly female spike

Pistillate flowers appear from the base of the spike covering the entire length with fruits. The staminate flowers are clustered at the base of the peduncle and sometimes dispersed in female flowers at the lower end only.

\section{Partially female spike}

Roughly the upper half of the spike length is full of pistillate flowers (and hence full of fruits) whereas the lower half bears staminate flowers and hence gives a vacant appearance.

\section{Mostly male spike}

Fruits clustered only at the upper one third of the spike. The remaining lower two-third is occupied by male flowers, which wither and thus give an empty look. The local varieties of Castor in Telangana region of A.P and also many other states are of this type.

\section{Shape of spike}

The shape of spike varies greatly. The different shapes are confined to the mostly female group described above. Mostly in male group there is no variation in the shape whereas in case of partially female group, certain shapes are distinguishable but are not so conspicuous.

The following are the more important shapes found in mostly female types:

\section{A. Long cylindrical}

Though the tip of the spike usually becomes narrow. Yet the whole appearance is like a narrow cylinder with uniform diameter.

B. Long conical

At the base, the spike is broad and becomes very narrow at the tip thus giving an appearance of a cone.

\section{Compactness of raceme/ spike}

This character is clearly distinguishable mostly female Racemes. In case of partially female and mostly male types, the Raceme are usually loose to very loose. The length of the Raceme on which fruits are borne and the number of fruits gives a measure of compactness. This can be expressed in terms of fruits per linear length. 
The following are the main types noticed

A. Firmly compact: Fruits are set very close and no space is left between fruits.

The fruits cannot move. This type harbors/ give shelter to insect pests and is not suitable for field crops.

B. Compact: Fruits are set close to each other but slight space is left in between fruits.

C. Loose: Fruits are set well apart from one another.

D. Very loose: Fruits are very much farther apart.

\section{Nature of fruits}

Spiny, Non-spiny

In case of spiny fruits there is variation in the length of spines. In some cases, the spines are short and in some long. There are about 150 spines per fruit.

In case of non-spiny fruits, the skin of the fruit is generally smooth. The non-spiny fruits can be further sub-divided into two groups, (I) smooth and (ii) warty where the epicarp is rugged.

Size of Fruits

There is great variation in the size of fruits.

In general, the size of seed is in direct proportion to the size of fruits.

The size of fruits could be divided into four major groups, namely:
a. Very small
b. Small
c. Medium and
d. Large.

The large fruits usually contain large seeds which have a low oil content, i.e., less than 40 per cent on the whole seed. The medium and small seeds are the two groups to which most of the cultivated varieties of castor. Their oil content varies from 45 per cent to 57 per cent. Very small fruits are usually found in ornamental plants in some perennial types and sometimes as a variation in cultivated varieties.

\section{Color of Fruits}

Practically, all cultivated varieties have green fruits.

But plants with pink and Sulphur-white fruits have also been observed and isolated.
Seed features

Locules in Fruits

There are usually three locules in castor fruit. But fruits with two and four locules have also been noticed.

Fruit Dehiscence

The local varieties raised by the farmers are all dehiscent and hence harvesting of fruits has to be done before the fruits are completely dry. The harvested fruits are then dried in the sun and threshed. Dehiscent fruits are very easy for threshing, but harvesting them before full maturity affects the oil content.

\section{Seed Size}

There is a great range of variation in seed size.

The smallest seed noticed is $7.95 \mathrm{~mm}$. X $5.30 \mathrm{~mm}$., while the largest is $20.95 \mathrm{~mm}$. X $13.50 \mathrm{~mm}$.

Between these two extremes all intermediate stages could be found. The common cultivated types have seedsize ranging from $11.19 \mathrm{~mm}$. X $7.79 \mathrm{~mm}$. to $13.54 \mathrm{~mm} \mathrm{X}$ $9.80 \mathrm{~mm}$.

\section{Seed Color}

A number of colors are to be found in castor seed.

The most striking ones are: - Red, white, grey, faint chocolate, deep chocolate and purple.

Mottling on Seed

A great variation is to be found in the expression of this character.

The range is from no mottling to such thick mottling, that at times it is difficult to distinguish between the ground color and the color of mottling.

Space filled by endosperm within the seed coat In most cases, the endosperm completely fills the space within the seed coat.

This makes the seed heavy and difficult to be crushed easily by pressing with fingers.

But there are medium-seeded varieties where the endosperm does not fully fill the space within the seed coat.

Such seed is easy to crush by pressing with the thumb. This should not be confused with shrunken endosperm resulting from want of moisture in the field at the time of seed formation. This character of the endosperm not filling the seed cavity completely, causes some damage to seed at the time of threshing. With seed that is well filled, there would be hardly any broken seed after threshing, but with seed that is not well filled with endosperm, there would be usually about five per cent broken seed at the end of threshing. 
In conclusion, castor varies greatly in its growth and appearance. The stem is round and glabrous, sometimes covered with an appearance on the field. The leaves are large, often dark glossy green with long petioles. The flowers are borne on inflorescence which forms a pyramidal raceme known as spikes or candle. The racemes are borne terminally on main and lateral branches. The fruit is usually a schizocarp; a spiny capsular fruit with three cells each of which splits open at maturity. Castor plant grows naturally over a wide range of geographical regions and similarly can be cultivated under a variety of physical and climatic regimes.

Castor plant is seen as an ideal candidate for agricultural revenue-generating produce which has the potential to become the premier vegetable oil for industries across the country. The high potential yield and unique fatty acid composition allow castor oil to produce economically competitive feedstock needed for production of premium quality biodiesel, short chain aviation fuels, derived fuel lubrication additives and very high value biopolymers.

However, integrated research efforts to boost the global production of castor are critical roles of the scientists. The researchers who are working on castor should cultivate increased international cooperation in development of solutions to the main constrains to castor production, processing and marketing. The research priority should be placed on holistic castor collection and characterizations, and development of technology for improved varieties and completely mechanized castor production. Waxy bloom which gives red or green stems a bluish.

\section{References}

Allan, G., Williams, A., Rabinowicz, P.D., Chan, A., Ravel, P., Keim, J.P., 2008. Worldwide genotyping of castor bean germplasm (Ricinus communis L.) using ALFP and SSRs. Genet. Resour. Crop. Ev. 55, 365-378.

Akande TO, Odunsi AA, Olabode OS, Ojediran TK. 2012. Physical and nutrient characterization of raw and processed castor (Ricinus communis L.) seeds in Nigeria. World Journal of agricultural Sciences8: 89-95.

Ani, A.O. and Okorie, A.U. (2009). Response of broiler finishers to diets containing graded levels of processed castor oil bean (Ricinus communis L.) meal. J. Anim. Physio. Anim. Nutr. 93:157 - 164.
Anjani, K., 2000. Catalogue of Castor, vol. 1. Directorate of Oilseeds Research, Hyderabad, India.

Armuganathan, K., Earle, E.D., 1991. Nuclear DNA content of some important plant species. Pl. Mol. Biol. Rep. 9, 208-218.

Auld, D.L., Pinkerton, S.D., Boroda, E., Lombard, K.A., Murphy, C.K., Kenworth, K.E., Becker, W.D., Rolfe, R.D., Ghetle, V., 2003. Registration of TTULRC castor germplasm with reduced levels of ricin and RCA120. Crop. Sci. 43, 746-747.

Auld, D.L., Rolfe, R.D., McKeon, T.A., 2001. Development of castor with reduced toxicity. J. New Seeds 3, 61-69.

Bhardwaj, H.L., Mohamed, A.I., Webber III, C.L., Lovell, G.R., 1996. Evaluation of castor germplasm for agronomic and oil characteristics. In: Janick, J. (Ed.), Progress in New Crops. ASHS Press, Alexandria, VA, pp. 342-346.

Barnes, D. J., Baldwin, B. S., and Braasch, D. A. 2009. Ricin accumulation and degradation during castor seed development and late germination. Industrial Crops and Products, 30(2), 254-258. doi: 10.1016/j.indcrop.2009.04.003.

Bajay, M.M., 2010. Development of microsatellite markers and characterization of germplasm of castor (Ricinus communis L.). Dissertation, Universidade de Sao Paulo-USP, Brazil.

Brigham, R.D., 1967. Inheritance of two female-sterile characters in dwarf-internode castor (Ricinus communis L.). Crop Sci. 7, 648-650.

Carter, S., Smith, A.R., 1987. Euphorbiaceae Flora of Tropical East Africa. A.A., Balkema Publishers, Rotterdam, Netherlands.

Chan, A.P., Crabtree, J., Zhao, Q., Lorenzi, H., Orvis, J., Puiu, D., Melake-Berhan, A., Jones, K.M., Redman, J., Chen, G., Cahoon, E., Gedi, B., Stanke, M., Haas, M., Wortman, B., Fraser-Liggett, J.R., Ravel, C., Rabinowicz, J.P.D. 2010. Draft genome sequence of the oilseed species Ricinus communis. Nat. Biotech. 28, 951-956.

Conceicao, M.M., Candeia, R.A., Silva, F.C., Bezerra, A.F., Fernandes Jr., V.J., Souza, A.G., 2007. Thermo analytical characterization of castor oil biodiesel. Renew. Sustain. Energy Rev. 11, 964975.

Da Silva Ramos, L.C., Tango, J.S., Savi, A., Leal, N.R., 1984. Variability for oil and fatty acid composition in castor bean varieties. J. Am. Oil Chem. Soc. 61, 1841-1843.

Drown, D.C.; Harper, K. and Frame, E. (2001). Screening vegetable oil alcohol esters as fuel 
lubricity enhancers. J. Am. Oil Chem. Soc. 78:579584.

Falasca SL, Ulberich AC, Ulberich E. 2012. Developing an agro-climatic zoning model to determine potential production areas for castor bean (Ricinus communis L.). Industrial Crop and Products 40:185191. DOI: 10.1016/j.indcrop.2012.02.044

Foster, J., Allan, T., Chan, G.J., Rabinowicz, A.P., Ravel, P.D., Jackson, J., Keim, P.J.P., 2010. Single nucleotide polymorphism for assessing genetic diversity in castor (Ricinus communis L.). BMC Plant Biol. 10, 13.

George Jr., W., Shifriss, O., 1967. Interspersed sexuality in castor. Genetics 57, 347-356.

Gupta, A.P.; Antil, R. S.; and Narwal, R.P. (2010). Utilization of deoiled castor cake for crop production. Arch. Agron. Sci. 50:389-395.

ICOA. (1989). The processing of castor meal for detoxification and deallergenation. International Castor Oil Assoc., Cinnaminson, NJ.

Jacob, K.M., Atsmon, D., 1965. Sex inheritance in Ricinus communis L.: evidence for a genetic change during the ontogeny of female sex reversals. Genetica 36, 253-259.

Jacob, K.M., 1963. A trisomic male castor bean plant. J. Heredity 54, 292-296.

Joshi, W.V., 1926. Some variations in the inflorescence of the castor plant. Poona Agric. College Magz. 18, 26-29.

Ladda PL, Kamthane RB. 2014. Ricinus communis (Castor): An overview. International Journal of Research in Pharmacology and Pharmacotherapeutics 3: 136-144.

Lima, R.I.S.; Severino, S.; Sampaio, I.R.; Sofiatti, V.; Gomes, J.A. and Beltrao, N.E.M. (2011). Blends of castor meal and husks for optimized use as organic fertilizer. Ind. Crops Prod. 33:364-368.

Lima, R.I.S.; Severino, S.; Silva, M.I.L.; Vale, I.S. and Beltrao, N.E.M. (2006). Recipients volume and substrate composition for castor seedlings production. Ciencia Agrotecnol. 30:480-486.

Moshkin, V.A. (Ed.), 1986. Castor. Amerind Publishing Co. PVT Ltd, New Delhi. Narain, A., Singh, P., 1968. Haploid meiosis and its bearing on the constitution of the castor oil plant. J. Heredity 59, 287-288.

Mutlu, H. and Meier, M.A.R. (2010). Castor oil as a renewable resource for the chemical industry. Eur. J. Lipid Sci. Technol. 112:10-30.

Okoh, J.O., Ojo, A.A., Vange, T., 2003. Combining ability and heterosis of oil content in six accessions of castor at Makurdi. Nat. Sci. 5, 18-23.
Ogunniyi, D.S. (2006). "Castor Oil: A vital industrial raw material". Bioresour. Technol., 97(9): 10861091.

Pinkerton, S.D., 1997. Selection of castor with divergent concentrations of ricini and RCA using radial immunodiffusion. Masters Thesis. Texas Tech University, Lubbock, TX, USA.

Pinkerton, S.D., Rolfe, R.D., Auld, D.L., Ghetie, A., Lauterbach, B.F., 1999. Selection of castor with divergent concentrations of ricini and Ricinus communis agglutinin. Crop Sci. 39, 353-357.

Pompeu, R.C.F.F. (2009). Substituicao do farelo de soja pela torta de mamonadestoxificadaemdietas para ovinos: Valor nutritivo e desempenhobioeconomico. Ph.D. diss. Univ. Federal do Ceara, Fortaleza. (In Portuguese, with English abstract.).

Popova, G.M., 1926. Bulletin of applied botany. Plant Breed. (Leningrad) 16, 145-240.

Refaat, A.A. (2009). Correlation between the chemical structure of biodiesel and its physicalproperties. Int. J. Environ. Sci. Technol. 6:677-694.

Rojas-Barros, P., de Haro, A., Munoz, J., FernandezMartinez, J.M., 2004. Isolation of a natural mutant in castor with high oleic/low ricinolic acid content in oil. Crop Sci. 44, 76-80.

Roxburgh, W., 1874. Flora Indica. Calcutta Thacker Spink and Co.

Santos, R.F.; Barros, M.A.L.; Marques, F.M.; Firmino, P.T. and Requiao, L.E.G. (2001). Analise conomica. In D.M.P. Azevedo and Lima, E.F., editors, O agronegocio da mamona no Brasil. Embrapa Algodoa/ EmbrapaInformacao Tecnologica, Campina Grande, Brasilia, Brazil. Pp. 17-35.

Shifriss, O., 1957. Sex categories in Ricinus. Weiz Institute Report (1955-1956), 154-155.

Shifriss, O., 1960. Conventional and unconventional systems controlling sex variations in Ricinus. J. Genet. 57, 361-388.

Singh R, Geetanjali. 2015. Phytochemical and Pharmacological Investigations of Ricinus communis Linn.Algerian Journal of Natural Products. 3: 120-129.

Verma, K.K., Kendurakar, P.S., Tiwari, N., Prasad, R.N., 2007. Phsio-chemical characteristics of some castor bean (Ricinus communis) varieties, hybrids and genotypes. Ind. J. Agric. Biochem. 20, 43-45

Wilson, R.; Van Schie, B.J.; Howes, D. (1998). "Overview of the preparation, use and biological studies on polyglycerol polyrecinoleate (PGPR)". Food Chem. Toxicol., 36(9-10): 711-8.

Woodend, J.J., 1993. Collecting and evaluation of indigenous perennial castor (Ricinus communis L.) 
in Zimbabwe. Pl. Genet. Resour. Newslett. 94/95,18-20.

Zimmerman, L.H., Smith, J.D., 1966. Production of F1 seed in castor-beans by use of sex genes sensitive to environment. Crop. Sci. 6, 406-409.
Zheng, L., Qi, J., Fang, P., Su, J., Xu, J., Tao, A., 2010. Genetic diversity and phylogenetic relationship of castor germplasm as revealed by SRAP analysis. J. Wuhan Botanical. Res., CNKI: SUN: WZXY.0.2010-0-002.

\section{How to cite this article:}

Kedir Wulchafo Hussen. 2021. Genetic Diversity Assessment and Biological Description of Caster bean crop (Riciunus communis L.). Int.J.Curr.Res.Aca.Rev. 9(01), 59-69.

doi: https://doi.org/10.20546/ijcrar.2021.901.005 